ESJ Humanities

\title{
Legal Governing of e-contracts in Georgian Legislation
}

\author{
Tea Edisherashvili \\ PhD Undergraduate, Grigol Robakidze University, Georgia \\ Assistant Professor, Grigol Robakidze University, Georgia \\ Head of Legal Provision and Labor Safety Administration at LEPL National \\ Statistics Service of Georgia
}

Doi:10.19044/esj.2021.v17n2p1

Submitted: 30 July 2020

Accepted: 14 January 2021

Published: 31 January 2021
Copyright 2021 Author(s)

Under Creative Commons BY-NC-ND

4.0 OPEN ACCESS

Cite As:

Edisherashvili T. (2021). Legal Governing of e-contracts in Georgian Legislation. European Scientific Journal, ESJ, 17(2), 1. https://doi.org/10.19044/esj.2021.v17n2p1

\section{Abstract}

Technical progress has essentially changed the social world of humans. Civil turnover has encompassed the contracts already signed using e-means which saves time, consolidates commercial relations, and increases commercial efficiency. This is one of the many reasons why signing e-contract in recent decades has become popular worldwide and is demanding. Constantly promoting and changing technologies has put law against serious challenges. Aside the international legal acts, it has become necessary to make amendments in national legislation, which together with national characteristics is in harmony with international conventions and directives. The global pandemic in 2020 has resulted to the special need for developing internet commercial infrastructure (Smartloan.ge, 2020). This paper focuses on examining the legislation applicable in Georgia in the field of e-commerce, namely Civil Code (1997), Georgian laws: "About e-communication" (2005), "About e-document and free flow code" (2012), "About e-document and reliable e-service" (2017). Despite the fact that indicated laws (particularly the last two bills adopted recent years) is at certain extent in relevance with the international acts acknowledged internationally, e-commerce which is subject to applicable legislation is not regulated perfectly. The aim of this paper is not only the review of the above mentioned legislation, but it also establishes some recommendations for making Georgian legislation perfect in the field of ecommerce. Georgian legislation applies no regalements for directly signing econtracts, namely the customer, as well as non customer contract governing 
mechanisms. Certain statements and principles of applicable Georgian Civil Code, in addition to Georgian law about e-document and reliable e-service, at the moment of signing the contract and at pre-contract stage which regulates separate issues that are specific to e-communication does not create legal principles. For the purpose of eradicating the mentioned discrepancies, it is necessary to make exact regalement of e-commerce by adopting e-commerce (applicable in whole range of countries) while considering its specification.

Keywords: E-contract, contract form, e-signature, protection of customers

\section{Introduction}

E-commerce is an industry where customers and sellers contact one another through the internet (Smartloan.ge, 2020).

The role of electronic commerce has become more important for Georgia as well as for the whole world. This is as a result of the change in the conduct of customers and the rapid development of digital technologies (Smartloan.ge, 2020).

For the purpose of economic development and stable investment atmosphere, it was an important challenge for Georgia to establish contractbased relations through electronic means with foreign companies and providing support to local businesses. From this point of view, the relevant legislative base, refining legislation, is not only desirable for Georgia but also binding. In June 2014, Georgia signed the Association Contract with Europe with which Georgia has undertaken to approach its legislation to EU legislation and international legal instruments.

The Association Contract is the most recent ambitious relation between Georgia and EU. It evidences the commencement of completely new stage of development of Georgian judicial creative work, which is conditioned with its legally binding features (Samkharadze, 2015).

The contract aims at the creation of deep and overwhelming free commercial space between Georgia and EU. The sub-par. 1 of Article 6 of Contract is related to electronic commerce. According to Article 127 of the Contract, parties acknowledge that electronic commerce in many sectors increase their commercial possibilities and agree to assist the development of electronic commerce among them. According to Article 128, Georgia has undertaken to handle dialogue on various issues of regulating electronic commerce, including protecting customers, subject to electronic commerce. To execute other numerous obligations foreseen under this contract, a 5-year term was determined after it enters into force (Georgia, 2014).

Through the EU4Digital initiative, the EU promotes trade facilitation and harmonization between the Eastern Partnership countries and the EU. This 
is done by supporting common frameworks for e-commerce, e-customs and elogistics, as well as working on digital transport corridors (EU4Digital, 2020).

To prevent the spread of COVID-19, the Georgian government has banned online trading across the country. The bans did not only apply to postal items but also food supplies. However, representatives of local companies engaged in online trading think that the government made the wrong decision and have caused serious damage to local businesses. Since the spread of the virus has become a global problem, restrictions have affected many businesses, including online retailers. This issue was especially painful for Georgia because unlike other countries, only certain types of products can be purchased at this stage. This in itself has negatively affected the development of business, although the online sales platform in Georgia worked flawlessly before the virus spread and is not as popular as Amazon in America, China Taobao, etc. (Bregadze, 2020).

The interest of large companies in e-commerce clearly shows that this field is developing and growing. About $20 \%$ of the world's retail trade is ecommerce. In Georgia, this figure does not exceed $2 \%$. Like China, where consumer isolation due to the spread of the virus in 2003 helped boost the role of e-commerce in the market, Georgia has a unique opportunity to use the challenge as an opportunity to develop e-commerce in the country. The development of e-commerce will lead to the necessary processes such as job creation and finding key markets for entrepreneurs. Hence, this will result to the development of local production. Currently, there are more than 300 large and small online stores in Georgia. The number of self-employed people who independently trade in subscribed or hand-made products independently through various online platforms exceeds thousands (Bregadze, 2020).

The innovative means, distance and electronic commerce development of signing contract, the yet not seen electronic media and internet progress, have made the adaptation of economic and legal institutes to be necessary with new technologies and commercial regulations (Lakerbaia, 2016, p. 89).

In Georgian legal literature, there is no homogeneous notion for electronic contract. With general attitude, it encompasses the electronically achieved contract through the way of using technological means by two or more people. It is a fact that is based on traditional comprehension, the paperbased contract differs from electronic one, which is modeled completely through a software system and is controlled relevantly. This difference requires the regulation varied from traditional ones as well.

Consequently, there are several acts which regulate issues related to electronic contracts, including The Electronic Commerce (EC Directive) Regulation (2002) (EU PARLIAMENT, https://eurlex.europa.eu/homepage.html, 2000) and directive about electronic signatures (COMMUNITIES, 1993). The latter has been cancelled under "Regulation 
(EU) No 910/2014 of the European Parliament and of the Council of 23 July 2014 on electronic identification and trust services for electronic transactions in the internal market and repealing Directive 1999/93/EC" (EU PARLIAMENT, https://eur-lex.europa.eu/homepage.html, 2014), The consumer protection (Distance Selling) Regulations (2000) (EU PARLIAMENT, https://www.legislation.gov.uk/, 2002), Rome 1 convention (contractual obligations) (EU PARLIAMENT, https://eurlex.europa.eu/homepage.html, 2008), CISG and other.

On the basis of basic statements of Model Laws and indicated directives, many countries of the world have adopted regulatory legislative acts of electronic signatures and electronic commerce.

Despite the fact that in the world, as well as in Georgian customer market, the signing of contract using electronic means has been widely spread. However, there is no reflection of this made in Georgia at the legislative level of this relation (Pachuashvili, 2017, p. 102).

Nowadays, neither Civil Code of Georgia nor either other legislative acts do not include statements in distance, including electronic contracts (Lakerbaia, 2016, p. 87). Also, several legislative acts which are examined in article, indirectly regulates the mentioned issue.

The article is in conjunction with legal acts and case law based on the research issue. The paper comprises of abstract, introduction, review of separate law governing electronic contracts, and conclusion.

\section{Civil Code of Georgia}

Article 69 of Civil Code of Georgia (Georgia, www.matsne.gov.ge, 1997) is related to simple as well as complex written forms of deal. According to Part 3 of the same Article, the revealing of will in written form requires the presence of signature. In civil turnover, like in terms of doctrine (Zambakhidze, 2005, p.118) and judicial practice (Resolution, 2016), electronic contract is assessed as simple written form contract equalized with the relevant one. The aim of equalizing electronic form with the written one is to establish the identity of will revealing entity, checking its authenticity, and avoiding the possibility of falsification.

According to Section 2, Article 328 of Civil Code of Georgia, if parties agree on written form, contract may be signed with one document signed by the parties. To provide the form, a telegraph notification, TV copy or letter inter-change is enough. It is possible to inter-change letters by using ordinary mail. Thus, if parties agree in advance to sign written form contract electronically, then the electronic documents executed by them with their legal features will be equalized with paper-based material documents, i.e., the contract is signed following the written form. Also, it is necessary to 
consolidate the mentioned functional-equivalent attitude in a legislative way (Todua, 2019, p. 49).

Consequently, the principle of freedom of form rises due to the Civil Code of Georgia indirectly. However, the vagueness of formulating relevant norm should not become the reason for saying that the form freedom is not acknowledged. This is because the consolidation of this latter is conditioned by the presence of contract's freedom, and it is expressed by determining the binding form of a deal rising from the principle of form freedom as exception (Amiranashvili, 2018, p. 270).

The Civil Code of Georgia is different from some countries (Germany, Russia) and does not include special norms in relation to electronic contracts. Nonetheless, considering the general norm regulating the form of a deal (contract), it is possible to sign electronic contract.

Subject to the current reforms of civil jurisprudence, the adoption of regulations about "electronic form" should be put into consideration. This would replace the written form in the case of applying e-mails and similar means. The possible models mentioned are regulations of separate countries or international ones, as well as EU Parliament and Council directives (Amiranashvili, 2018). It is also important to note how to organize the special issues subject to Civil Code around electronic commerce (Amiranashvili, 2018).

\section{Georgian Law "about Electronic Document and Reliable Electronic Service"}

Georgian law "about electronic signature and electronic document" adopted in March $14^{\text {th }}, 2008$, has been announced as invalid. This was amended by Georgian law "about electronic document and reliable electronic service" adopted in April $21^{\text {st }} 2017$ (Georgia, www.matsne.gov.ge, 2017).

In 2008, after the law was adopted, some factual circumstances have essentially changed in Georgia. For example, electronic identity card (temporary) and relevant infrastructural means have been implemented. Furthermore, the possibility of making digital signature has become possible. The experiences gained by the authorities in recent years have made it clear on how to regulate issues of applying electronic document and electronic signature at legislative level.

The adoption of a new law was also conditioned by the necessity of harmonization of Georgian legislation with that of EU. Also, all the innovations are reflected in law, which are given in "Regulation (EU) No 910/2014 of the European Parliament and of the Council of 23 July 2014 on electronic identification and trust services for electronic transactions in the internal market and repealing Directive 1999/93/EC" (EU PARLIAMENT, https://eur-lex.europa.eu/homepage.html, 2014). 
Georgian law "about electronic document and reliable electronic service" mostly relies upon technical terms such as "digital signature," "cryptography," "open and closed keys," etc. More so, some technical term of general application (for example, "open key," "closed key") have been applied in previously applied law with narrow content. This is specifically seen in some part of digital signature, which in turn could not be applied in the right way. To this extent, it was irrelevant to the legislative practice established in EU. This refers to the application of relatively neutral terminology from a technological point of view.

Regardless of the digital signature, which is one of the forms of reliable service, the previous law did not regulate the application of other reliable service such as qualified electronic stamp, qualified determination of authenticity of signature/stamp, qualified denotation of time, and qualified storage of qualified electronic signature/stamp related services. Nevertheless, it became necessary to adopt new law which reflected not only the legal principles of using electronic signature but also those of reliable service (Article 1.1).

The applicable law does not limit the freedom of citizen's will to determine the public relation form, whether in material or electronic form. Also, private legal entities have the right to determine the material or electronic document application (Article 1.2).

The applicable law is targeted at determining the legal mechanisms using electronic signature and other reliable service. This provides assistance to electronic management, electronic business development and other directions, and provides relevance to the Georgian legislation with a legal framework subject to EU.

The mentioned law provides the creation of electronic and electronically signed documents (documents which have never been submitted in paper-based form) (Todua, 2019, p. 15). This in turn significantly decreases the paper-based document turnover and increases the degree of document protection.

It is worthy to note that Georgia constantly improves its positions in electronic management and open management issues as highlighted below:

1. According to UN electronic management index, Georgia occupied $56^{\text {th }}$ place among 196 countries in 2014. With this indicator, it is on promoted positions and runs before such countries such as Turkey, Romania, Bulgaria, Ukraine, Armenia, and Azerbaijan. In 2008, Georgia occupied $100^{\text {th }}$ place in the mentioned rating. Index is also updated once in every 2 years.

2. According to open management index, which determines the openness of governments in the world, Georgia occupies first place between 13 countries of East Europe and Central Asia and generally $29^{\text {th }}$ place 
among 102 countries. In 2014, Georgia was selected as Open Management Partnership Managing Committee member. In 2017, it occupied the country's position of Deputy Chairman. Georgia in the initiative of open management is exemplary with its active participation of legislative and judicial branches and ambitious plans as well as democracy, thereby elevating the trust towards government and reforms addressed to activity transparency (Ministry of Justice, 2016).

According to law, throughout the country, the electronic document and reliable electronic service are widely spread. The early applicable law, which limited only court in waiver on electronic document, is different from the new law which practically obliges the public authorities not to waive electronic document with the motto that it is not submitted in material form (in paperbased version) (Article 3.7). Also, it is possible to apply electronic document in all the cases when the written form of document is requested or foreseen under legislation (Article 4.2).

The indicated par. 4.2 of the law is of blanket mood. Therefore, it is necessary to determine cases related to specific deals or contracts, which should be signed in written form. In addition, the agreement of parties for using electronic form is excluded, when written form has intention seriousness/warning function carrier. Based on Georgian legislation, such cases should not be assessed as activity of freedom of form (Amiranashvili, 2018, p. 271).

The idea of new law differently considers and interprets the notion of electronic signature. As a result of new legislative changes, the qualified electronic signature is given legal power of material signature. The person may have the opportunity of using electronic document in cases when the written form of document is requested (if not otherwise, it is considered by legislation) (Ministry of Justice, 2016).

Based on new law, electronic signature is not the system of graphic signs. This is the system comprising of the combination of binary signs, zeros, and ones (Ministry of Justice, 2016).

According to law, the issue of qualified electronic signature is regulated in details. The preconditions of its usage are determined and the high quality is based on its reliability. The qualified electronic signature verifies the identity of signer and protects the signed document. Also, with the development of electronic management, administration costs are significantly decreased and the green cover and its environment are saved (Ministry of Justice, 2016). 
New law does not regulate the list which is determined under Article 3 of old law. It carries blanket mood in difference with its predecessor (Amiranashvili, 2018, p. 90).

The law established such notions such as "qualified electronic signature," "qualified electronic stamp," "signature creation data," "signature checking data," "qualified reliable service provider" and others.

The applicable law determined and subordinated the qualified reliable service to regulation. The requirements towards qualified reliable service provider for the protection of high standards were also refined. This includes the qualified electronic signature which is given the legal power equal to personal signature (Article 5). In previously applicable law, from the point of safety, it was less strictly established when carrying out certain risk.

The strict regulation of qualified reliable service provider's activity given in law provided the opportunity for the country to start the process. This was done for the purpose of acknowledging the qualified reliable service taking place in Georgia in EU member states. In order to achieve this aim, the law has determined the obligation of supervision. This is different from the early applicable law which considered only the voluntarily accreditation (Article 5.2).

The law has also regulated the issues of acknowledging qualified reliable service applicable abroad. In relevance with the law, if Georgia has signed the contract with international legal entity, which includes the issues related to electronic signature, the qualified reliable service or international organizations or the ones applicable in other countries will be given the legal power equal to the qualified reliable service applicable in Georgia (Article 12).

The law has also clearly regulated the rule of using qualified electronic stamp on behalf of legal entities, which somehow pushed the development of electronic signature and the spread of electronic document. For example, it became possible to issue the official documents by administrative functional authorities in electronic form in order not to make it necessary to publish the electronic versions of these documents at the web-portals with high availability (Article 4.4), different from early existing condition. Any private legal entity was given the opportunity to create such environment. However, based on the user's identification, the service will be provided. This is particularly important for banking, insurance, and healthcare sectors. The law has also offered the implementation of electronic signature and electronic stamp, which significantly assists businesses and the development of electronic commerce in the country.

According to Article 11 of the law, the qualified reliable service provider is obliged to make authorization at LEPL - Date Exchange Agency operating in the field of management of the Ministry of Justice of Georgia (hereinafter - Data Exchange Agency). 
Furthermore, many administrative authorities are processing documents in electronic form. When issuing relevant copies of these documents to citizens, they have legal power because electronic originals are kept at databases and are available through internet. Apart from operational expenses, it is necessary to have stronger server and other infrastructure and connection to the internet. It also includes information about damage or risk loss. On behalf of legal entity, the usage of qualified electronic stamp provides the issuance of electronic documents to stakeholders verified by autonomous and authorized authorities. When checking the correctness of electronic documents, it is not necessary to download them from issuing authority web resources.

One of the most important legislative novelties is legal regulation of qualified denotation of time. The qualified denotation of time provides the opportunity to confirm the presence of electronic signature on the document within a specific moment of time. This in turn makes it possible to establish qualified electronic signature's legal power (Article 7).

On the basis of law, it became possible to maintain qualified electronic signature/stamp for a long period of time, which represents qualified reliable service. This means the extension of reliability even after their technological duration period expires, and this represents the so-called "electronically born" documents' archiving precondition. The creation of this legal precondition is currently actual. This is because in Georgia, together with the progress of electronic document turnover, the so-called "electronically born" documents may be archived to avoid making any cessation happen in the process of storing document-based memory (Article 9).

Finally, according to law, though the electronic document is equalized with the material one and the issue of electronic signature is regulated according to directive, this law or other applicable normative act does not regulate other issues in relation to electronic commerce.

\section{Georgian Law "about Product Safety and Free Turnover Georgian Code" \\ The Georgian law "about product safety and free turnover} Georgian Code", which was adopted in 2012 (Parliament, www.matsne.gov.ge, 2012), has been amended by Georgian law "about user's rights" adopted in March $20^{\text {th }} 1996$. The law targets human health care, life, property and environment protection, while considering the best practice of developed countries. The refinement of increased technical safety object supervision, construction, standardization, accreditation, relevance assessment, metrology, and technical regalement statutory regulation is in accordance with the best practice applicable in developed countries (Article 1). This has led to the creation of a strong reason to decrease technical barriers 
in commerce, establish technical regalements, quality infrastructure and modern system, as well as regulate the consolidation of quality infrastructure and united codification.

Nothing is mentioned about electronic regulation directly in law. However, there are many important and considerable norms that regulate the relations between electronic commerce participants in remote areas when the manufacturer and customer face the deal.

For example, two volumes of law basically unite such norms, which are related to the obligations of product manufacturer. This in turn conditions the location of safe product in the market and provides complete information to customers about product manufacturer as well as the product itself.

According to Article 11 of law, the manufacturer is obliged to warn the customer about any noticeable or negligible risk, which includes when the product is used. This will provide the customer with the necessary information about the product, which gives him the chance to make the right choice.

The customer will have to be provided with the following information:

a) Title of the product and form;

b) The firm title and address of product manufacturer, and the title of the country where the product is manufactured;

c) In relevant case - the validity period of the product (the deadline for the product or date of manufacturing and storage), and the customer features which are being worsened during the time;

d) In relevant case - product weight and/or volume;

e) In relevant case - list of basic customer features of the products;

f) In relevant case - the consequence and safety usage regulations and terms of the product as well as the special storage terms.

The execution of new global attitude European directives was implemented. This has made Georgian legislation come closer to European best practice, which has significantly improved the commercial relations with European countries.

Through electronic contracts, relations are executed in the important segment of civil turnover. This provides electronic communication networks and/or supply of electronic communication service between customer and electronic communication network operator or electronic communication service supplier. The indicated relations "about electronic communication" are regulated under Georgian law, which has been adopted in 2005 (Parliament, www.matsne.gov.ge, 2005). The mentioned law determines the following: the legal and economic principles of activity through electronic communication networks and means throughout Georgian territory, the establishment and regulation principles of specific environment in this field, functions of national regulatory authority (National Commission of Communications of Georgia), 
rights and obligations of physical and legal entities during service providing, and holding electronic communication networks and means.

\section{Sociology Survey Results}

For the purpose of determining the implementation of electronic contracts in Georgia and their application, sociology survey has been made, which encompassed 338 applicants.

More than half of the applicants are mostly lawyers, economists or financial specialists, while the age of the majority is $31-45$ years.

Almost $90 \%$ of respondents gave positive response to the question: what is electronic signature? Less than $57.7 \%$ know about the types of electronic signature (simple, qualified) and even less than 59.5\% have applied it.

Furthermore, $89 \%$ of respondents have negative response to the question about the acceptability of the process of signing electronic document, and $59.2 \%$ of surveyed people do not trust electronic signature. According to $64.8 \%$ of respondents, the indicator of electronic documents in civil turnover in Georgia has been assessed as average. However, 91.4\% of respondents consider that in the future, civil turn will be developed on the basis of electronic documents.

\section{Conclusion}

In order to carry out market-economic relations in Georgia, it is necessary to have competitive entrepreneurial structures involved in electronic business and free entrepreneurial environment to create relevant legislative base. To develop electronic commerce, it is necessary to improve united legislative strategy according to its regalement in issues related to electronic contract.

Despite the fact that the legislation applicable in the field of electronic commerce is relevant to the international acts acknowledged in this field, from the point of creating stable legal mechanism for determining the rights and obligations of electronic contracting parties, the legislative amendments are necessary.

The issue related to the authenticity of electronic document and its legal acknowledgment should be given regalement with "functionalequivalent attitude," which is the foundation principles of Model Law of UNCITRAL. It is based on the analysis of functions and legal requirements raised for making paper-based documents. This determines how these aims and functions will be achieved or executed, which is subject to information technology framework. The consolidation of legislative rule of this attitude provides the following requirements raised to paper-based document through electronic means (Zambakhidze, 2005, p. 137). Also, it is important to have 
legislative regulation about sending electronic notification and its adoption regulation (time, place, and applicable law) (Zambakhidze, 2005, p. 137). In Georgian legal science, not a single author has indicated the necessity of adopting special law in the field of electronic commerce (Edisherashvili, 2016, p. 55; Andguladze, 2014, p. 92; Erkvania, 2011, p. 51).

Sociology survey results also indicate the necessity of legislative amendments. Furthermore, the creation of new law about electronic commerce and relevant amendments in separate laws (for example, special norm in Civil Code about electronic contracts) assists in the adaptation of Georgia with the world's developed economic systems.

\section{References:}

1. Amiranashvili, G. (2018). Forcing to make a deal as limitation of freedom of form. Tbilisi: meridiani.

2. Andguladze, K. (2014). E-mail based contract. Magazine of Jurisprudence.

3. Bregadze, L. (2020). E-commerce development tendencies and perspectives in Georgia" Master's Work. Tbilisi, Georgia.

4. COMMUNITIES, T. C. (1993, july 19). https://eurlex.europa.eu/homepage.html. Retrieved from https://eurlex.europa.eu/homepage.html: $\quad$ https://eur-lex.europa.eu/legalcontent/EN/TXT/?qid=1595061390916\&uri=CELEX:31993R1993

5. Edisherashvili, T. (2016, December ). Legal Regulation of Electronic Contract and General Review, European Scientific Journa, pp. 50-55.

6. Erkvania, T. (2011). European standards for customers' roghts protection in electronic commerce and Georgian legislation . Jurispridence and law, pp. 44-62.

7. EU PARLIAMENT, C. O. (2000, june 8). https://eurlex.europa.eu/homepage.html. Retrieved from https://eurlex.europa.eu/homepage.html: $\quad$ https://eur-lex.europa.eu/legalcontent/EN/TXT/?qid=1595060628281\&uri=CELEX:32000L0031

8. EU PARLIAMENT, C. O. (2002, July 30). https://www.legislation.gov.uk/. Retrieved from https://www.legislation.gov.uk/: https://www.legislation.gov.uk/uksi/2002/2013/introduction/made?vi ew=plain

9. EU PARLIAMENT, C. O. (2008, june 17). https://eurlex.europa.eu/homepage.html. Retrieved from https://eurlex.europa.eu/homepage.html: https://eur-lex.europa.eu/legalcontent/EN/ALL/?uri=celex\%3A32008R0593

10. EU PARLIAMENT, C. O. (2014, JULY 23). https://eurlex.europa.eu/homepage.html. Retrieved from https://eur- 
lex.europa.eu/homepage.html: $\quad$ https://eur-lex.europa.eu/legalcontent/EN/TXT/?qid=1595061657155\&uri=CELEX:32014R0910

11. EU4Digital. (2020, 04 07). www.eu4digital.ge. Retrieved 10 29, 2020, from www.eu4digital.ge: https://eufordigital.eu/geo/thematicarea/etrade/

12. Georgia, M. O. (2014, june 27). www.matsne.gov.ge. Retrieved from www.matsne.gov.ge:

https://www.matsne.gov.ge/document/view/2496959?publication=0

13. Georgia, P. O. (1997, June 26). www.matsne.gov.ge. Retrieved from www.matsne.gov.ge:

https://www.matsne.gov.ge/document/view/31702?publication=109

14. Georgia, P. O. (2017, april 21). www.matsne.gov.ge. Retrieved from www.matsne.gov.ge:

https://www.matsne.gov.ge/document/view/3654557?publication=1

15. Lakerbaia, T. (2016). On the example of waiver on European contract model of protecting the user's rights in contracts signed remote. $1, \mathrm{p}$. 89.

16. Ministry of Justice, G. (2016, December 19). www.parliament.gov.ge. Retrieved from www.parliament.gov.ge: https://info.parliament.ge/file/1/BillReviewContent/137829

17. Pachuashvili, M. (2017). Meaning of regulating eleqtronic contract in Georgian legislative space. 2, p. 102.

18. Parliament, G. (2005, June 02). www.matsne.gov.ge. Retrieved from www.matsne.gov.ge:

https://www.matsne.gov.ge/document/view/29620?publication=39

19. Parliament, G. (2012, May 08). www.matsne.gov.ge. Retrieved from www.matsne.gov.ge:

https://www.matsne.gov.ge/document/view/1659419?publication=32

20. Resolution , AS-898-848-2015 (Supreme Court of Georgia March 9, 2016, ).

21. Samkharadze, I. (2015). Harmonization of Legal Systems: EU and Georgia. 1, pp. 314-330.

22. smartloan.ge. (2020, 04 18). www.smartloan.ge. Retrieved 10 30, 2020, from www.smartloan.ge: https://smartloan.ge/\%e1\%83\%91\%e1\%83\%9a\%e1\%83\%9d\%e1\%8 $3 \% 92 \% \mathrm{e} 1 \% 83 \% 98 /$

23. Todua, T. (2019). https://openscience.ge/. Retrieved from https://openscience.ge/:

https://openscience.ge/bitstream/1/1033/1/samagistro\%20thodua.pdf

24. Zambakhidze, T. (2005). Legal principles of electronic commerce (problems and perspectives). Review of Georgian Law, 108-140. 